\title{
Mechanisms of Drug Resistance in Cancer Chemotherapy
}

\author{
Y.A. Luqmani \\ Department of Pharmaceutical Chemistry, Faculty of Pharmacy, Kuwait University, Kuwait
}

\author{
Key Words \\ Cancer $\cdot$ Chemotherapy $\cdot$ Drug resistance $\cdot$ \\ Multidrug resistance $\cdot \mathrm{P}$-Glycoprotein
}

\begin{abstract}
The management of cancer involves procedures, which include surgery, radiotherapy and chemotherapy. Development of chemoresistance is a persistent problem during the treatment of local and disseminated disease. A plethora of cytotoxic drugs that selectively, but not exclusively, target actively proliferating cells include such diverse groups as DNA alkylating agents, antimetabolites, intercalating agents and mitotic inhibitors. Resistance constitutes a lack of response to drug-induced tumour growth inhibition; it may be inherent in a subpopulation of heterogeneous cancer cells or be acquired as a cellular response to drug exposure. Resistance varies. Although regulatory approval may require efficacy in as few as $20 \%$ of trial cohorts, a drug may subsequently be used in unselected patients displaying resistance to the treatment. Principal mechanisms may include altered membrane transport involving the P-glycoprotein product of the multidrug resistance (MDR) gene as well as other associated proteins, altered target enzyme (e.g. mutated topoisomerase II), decreased drug activation, increased drug degradation due to altered expression of drug-metabolising enzymes, drug inactivation due to conjugation with increased glutathione, subcellular redistribution, drug interaction, enhanced DNA
\end{abstract}

repair and failure to apoptose as a result of mutated cell cycle proteins such as p53. Attempts to overcome resistance mainly involve the use of combination drug therapy using different classes of drugs with minimally overlapping toxicities to allow maximal dosages and with narrowest cycle intervals, necessary for bone marrow recovery. Adjuvant therapy with P-glycoprotein inhibitors and, in specific instances, the use of growth factor and protein kinase $C$ inhibitors are newer experimental approaches that may also prove effective in abrogating or delaying onset of resistance. Gene knockout using antisense molecules may be another effective way of blocking drug resistance genes. Conversely, drug resistance may also be used to good purpose by transplanting retrovirally transformed CD34 cells expressing the MDR gene to protect the bone marrow during high-dose chemotherapy.

Copyright $(2005$ S. Karger AG, Basel

\section{Types of Cancer Treatments}

Therapeutic procedures for cancer patients still remain largely empirical and vary between centres. Treatment depends upon a variety of individual factors, which may include the specific pathological and molecular characteristics of the cancer, its location, extent of disease and the health status of the patient.

The ultimate objective is to destroy all the cancer cells whilst inflicting minimal damage on the normal tissue.

\section{KARGER \\ Fax +4161306 1234 E-Mail karger@karger.ch} www.karger.com
(C) 2005 S. Karger AG, Basel

$1011-7571 / 05 / 0147-0035 \$ 22.00 / 0$

Accessible online at: www.karger.com/mpp
Prof. Y.A. Luqmani

Department of Pharmaceutical Chemistry, Faculty of Pharmacy, Kuwait University PO Box 24923

13110 Safat (Kuwait)

Tel. +965 533 7135, Fax +965 5342807, E-Mail yunus@hsc.edu.kw 
Fig. 1. Sites of action of cytotoxic agents.

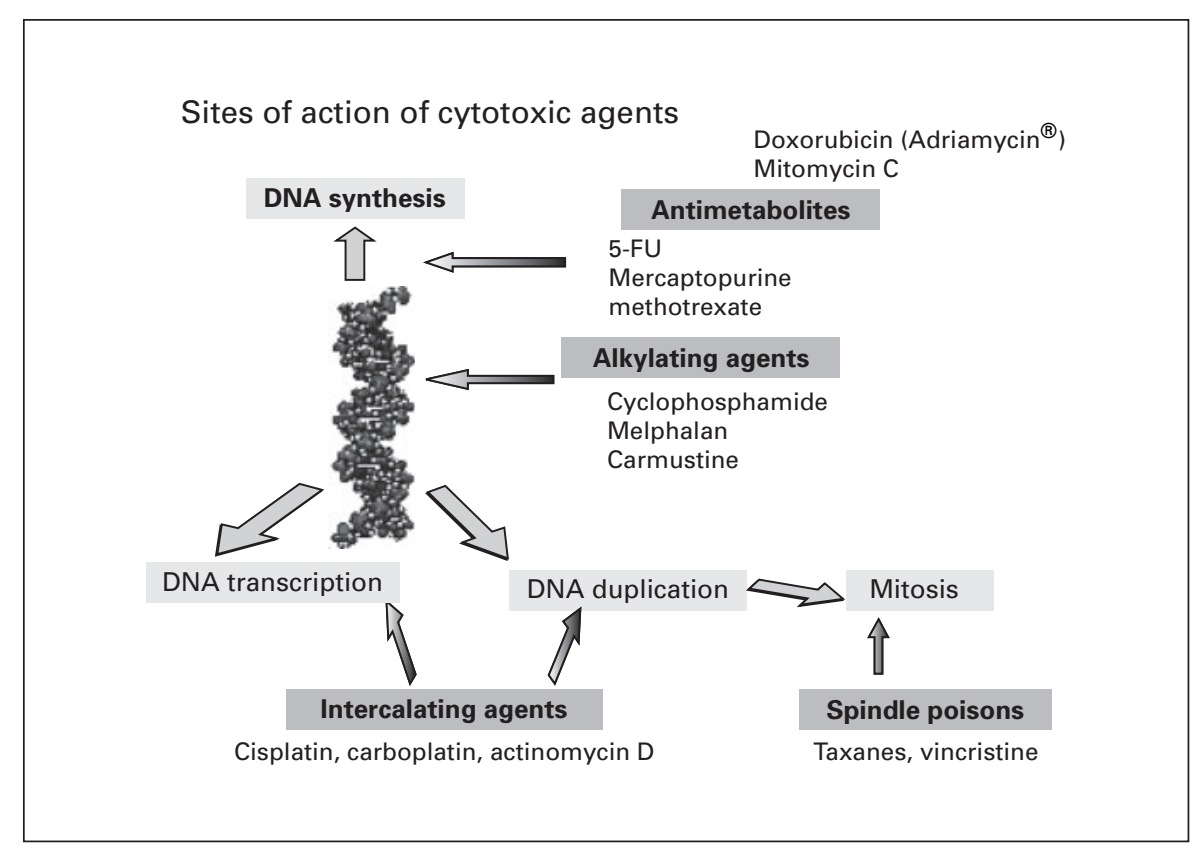

This can be achieved in a number of ways, either directly or indirectly by depriving the cancer cells of signals needed for cellular proliferation or by stimulating an immune response.

There are several different types of treatment, which may be used alone or in combination, either simultaneously or sequentially: surgery, radiotherapy and drugs. Surgery is most frequently the first line of therapy, and for 'early' cancers, it may be curative. Radiotherapy is most often used in a localised setting and in conjunction with surgical procedures. The use of drugs involves chemotherapy (CTX), which employs a wide group of drugs that have cytotoxic effects which preferentially, but not exclusively, target the rapidly dividing cancer cells. Endocrine therapy is a more specific form of treatment, used for example for breast cancer. It is aimed at preventing cancer cell proliferation by antagonising the oestrogenstimulated intracellular signals which control growth in cells overexpressing the oestrogen receptor. This may be effective in $60-70 \%$ of breast cancer patients. Antibodies against specific proteins that are overexpressed in cancer cells may be used to preferentially target those cells. Toxin molecules linked to the antibodies would be endocytosed into the cells and destroy them, such as Herceptin, which targets the erbB2/HER2/neu receptor [1-4]. Targeted therapies have been employed exploiting the overexpression in many cancer cells of proteins such as the folate receptor [5, 6]. Metabolic inhibitors are being in- vestigated, which target specific proteins and pathways involved in cell growth that operate preferentially in cancer cells. Many of these are associated with cell cycle regulation. Biological response modifiers are a class of compounds, which may be modulated to elicit an immune response against cancer cells. Vaccines may offer an ideal solution, but so far the lack of tumour-specific proteins has hampered this approach. Of these, chemotherapy and endocrine therapy are currently in use. Others are experimental or hopeful approaches for the future. This review describes the mechanisms of drug resistance in cancer chemotherapy.

\section{Chemotherapy}

Although adjuvant CTX is frequently used for primary tumours, its main use is to control overt disseminated disease. The excessively active growth-signaling pathways in cancer cells makes them susceptible to a wide range of drugs which target growth-signaling molecules and/or processes involved in cellular replication and expression (fig. 1). However, as these processes also drive normal cells, the effect is preferential and not exclusive, which results in the unwanted side-effects seen with these agents. Cells which are normally actively dividing, in particular the bone marrow constituents and those of the intestinal lining, are particularly susceptible. Disregulat- 
ed cell cycle events, due to mutations in cancer cells, do sometimes offer opportunities to target those cells without affecting normal cells.

The relatively wide spectrum of activity of cytotoxic drugs makes them a rather harsh and non-specific form of treatment that can only be tolerated for short periods. Indeed the effects of the treatment may sometimes cause more distress than the disease. These side-effects include dry flaky skin, loss of hair, nausea and vomiting, changes in taste and appetite, blood clotting problems, fatigue, depressed immune system and possible sterility. Most side-effects subside after the treatment is over, but sometimes there is permanent damage to the kidneys, heart, lungs or reproductive system. In general, however, benefits outweigh the disadvantages, and CTX is the commonest form of cancer therapy. This is less a reflection of its effectiveness than the lack of a better alternative. The other chemical therapies in the list above constitute some of these alternatives, but at present they play a subsidiary role in the armory of the oncologist.

Many of the CTX drugs that are employed are naturally occurring compounds extracted from plants, while others are synthetic. They can be divided into three major groups on the basis of their mode and site of action: antimetabolites, genotoxic agents and mitotic spindle inhibitors [7].

\section{Antimetabolites}

Examples of such drugs include folate, pyrimidine and purine antagonists.

Folate Antagonists or Antifolates. These are inhibitors of dihydrofolate reductase (DHFR), an enzyme involved in nucleotide metabolism. Folates are co-enzymes required for methylation and necessary for the formation of purines and thymidylate. Methotrexate reversibly binds DHFR after entering the cell via the low $\mathrm{pH}$ folate transporter, or by reduced folate carriers, reducing the available DHFR for reduction of the tetrahydrofolate precursors, i.e. folic acid and dihydrofolic acid. Methotrexate is used to treat a variety of malignancies including acute lymphocytic leukaemia, large cell lymphoma, highgrade lymphoma, choriocarcinoma and cancer of the breast, bladder, head and neck and bone as well as many inflammatory diseases.

Pyrimidine Antagonists. Three such compounds that are commonly used in cancer therapy are 5-fluorouracil (5-FU; Adrucil ${ }^{\circledR}$, Fluorouracil, Efudex ${ }^{\circledR}$, Fluoroplex ${ }^{\circledR}$ ), gemcitabine $\left(\right.$ Gemzar $\left.^{\circledR}\right)$ and arabinosylcytosine. These may block pyrimidine nucleotide formation or cause premature termination by themselves being incorporated into newly synthesized DNA. 5-FU also affects the processing of ribosomal, transfer and small nuclear RNAs. It may inhibit cell growth by preventing synthesis of thymine nucleotides from uracil nucleotides. It is used extensively in treatment of cancers of the breast, colon, stomach, rectum and pancreas.

Purine Antagonists. These inhibit synthesis of adenine and guanine, and the main examples are acyclovir, 6-mercaptopurine (Purinethol ${ }^{\circledR}$, Puri-Nethol ${ }^{\circledR}$ ) and 6-thioguanine. They are used to treat particularly acute lymphocytic or myelocytic leukaemia, lymphoblastic leukaemia and acute myelogenous and myelomonocytic leukaemias.

\section{Genotoxic Agents}

These either bind to DNA or indirectly damage it by affecting enzymes involved in replication, which leads to induced apoptosis. Hence, proliferating cancer cells are more sensitive than most normal cells, which undergo division less frequently. This class of drugs may be subdivided into several groups.

Alkylating Agents. These modify the bases of DNA, interfering with replication and transcription and leading to mutations. Cross-linking atoms in the DNA, preventing strand separation for synthesis or transcription, also cause damage. Base mispairing between strands is also induced by alkylation. Examples include cisplatin, cyclophosphamide, melphalan, mitomycin $\mathrm{C}$ and temozolomide.

Intercalating Agents. These bind in the grooves in the DNA helix, interfering with polymerase activity during replication/transcription. Examples are epirubicin and doxorubicin.

Enzyme Inhibitors. These block replication by inhibiting enzymes, such as topoisomerases. The mutagenic properties of these drugs make them carcinogenic and therefore their use entails additional risk of secondary cancers, such as leukaemia. Examples of these are etoposide, topotecan and irinotecan.

\section{Mitotic Spindle Inhibitors}

These disrupt mitosis by affecting the formation/function of spindle microtubule fibres required for chromosome alignment. They prevent the polymerisation of tubulin monomers and act in a cell cycle-dependent manner. They also affect normal cells but to a much lesser extent due to the lower frequency of cell division. The commonly used drugs in this category are the plant-derived vinca alkaloids and paclitaxel $\left(\right.$ Taxol $\left.^{\circledR}\right)$ and the synthetic docetaxel (Taxotere ${ }^{\circledR}$ ). 


\section{Failure of Chemotherapy}

In some cases, tumours may be refractory to treatment with some types of cytotoxic drugs. In many, if not most instances, patients who initially respond to CTX invariably show a loss of response later on, resulting in tumour regrowth. There are two probable causes for this: (a) the tumour cells may be inherently resistant possibly due to some genetic characteristic or (b) they may acquire resistance following exposure to the drug. In a typical scenario, 1 in $10^{6}-10^{7}$ cancer cells in a tumour is likely to have inherent resistance against a particular drug. A clinically detectable tumour has in the region of $10^{9}$ cells and it might therefore be expected to contain 10-1,000 drugresistant cells, which have the potential to repopulate the tumour despite destruction of the sensitive cells. Considering this, the probability of cure or containment is directly related to tumour size at onset of treatment. Aggressive CTX may often cure certain cancers, particularly childhood leukaemias, Hodgkin's disease or testicular cancers, because the few surviving drug-resistant cells may become susceptible to the immune system. Irrespective of how resistance to CTX arises, it poses a serious impediment to the successful elimination of the entire tumour mass. Drug resistance has been described as the single most common reason for discontinuation of a drug [8].

So why does drug resistance vary between individuals and for different drugs? The answer to this is probably quite simple. In order to obtain approval for use in cancer therapy, a drug may, in the original clinical trials, have been shown to be effective in anything from just 20\% upwards of a relatively small and possibly selected patient group. Afterwards it is likely that it is used on patients without any preselection. Attempts to overcome the resistance by the use of a different drug is the most obvious approach, but this offers only temporary respite and eventually results in the phenomenon of multidrug resistance (MDR), which is defined as the insensitivity of various tumours to a variety of chemically related or unrelated anticancer drugs, mediated by a process of inactivating the drug or removing it from the target tumour cells.

\section{Potential Mechanisms of Resistance}

Various hypotheses, some with more supporting experimental evidence than others, have been proposed to account for the phenomenon of drug resistance. Ironically, some of the mechanisms that could be utilised by cancer cells to resist cytotoxic drugs are probably evolved in normal cells as a defence mechanism against environmental carcinogens. The hypothesis include altered transport of the drug across the plasma membrane, genetic responses, enhanced DNA repair, alteration in target molecules, access to target cells, metabolic effects and growth factors.

\section{Altered Membrane Transport}

Probably one of the most significant forms of resistance against the variety of currently used antineoplastic agents is by the action of a group of membrane proteins which extrude cytotoxic molecules, keeping intracellular drug concentration below a cell-killing threshold. These ATP-dependent multidrug transporters belong to the ubiquitous superfamily of ATP-binding cassette (ABC) proteins, which have also been implicated in the resistance to infectious diseases such as AIDS and malaria. These proteins modulate absorption, distribution and excretion of many pharmacological compounds. There may be as many as 48 genes encoding $\mathrm{ABC}$ transporters. The $\mathrm{ABC}$ proteins have been grouped into 7 subclasses ranging from $\mathrm{ABCA}$ to $\mathrm{ABCG}$ [9-11] based upon genomic organization, order of domains and sequence homology.

The MDR 1 gene, which encodes P-glycoprotein (P-gp; MDR1, ABCB1) [12-15], a phosphorylated and glycosylated $170-\mathrm{kDa}$ protein of 1,280 amino acids, is the most widely observed mechanism in clinical transport-associated MDR [16-19]. Several other ABC transporters have been described: the MDR-associated protein 1 (MRP1, ABCC1), the mitoxantrone resistance protein (MXR1/ BCRP, ABCG2) [19-23] and the ABCB4 (MDR3) and $\mathrm{ABCB} 11$ (sister P-gp or BSEP) proteins involved in the secretion of hepatic phosphatidyl choline and bile acids, respectively [24], as well as transport of certain drugs [25]. In addition to MRP1, five homologues (MRP2-MRP6) have been cloned and overexpression of MRP2 was shown to confer MDR [21,26]. MRP3 and MRP5, which are transporters of organic conjugates and nucleosides, respectively, are also implicated in drug resistance [21]. The MRPs ubiquitously expressed in normal tissues and to varying degrees in human cancers [27] belong to the ABCC subfamily comprising 11 genomic regions. Many of these proteins have been identified as ATP-dependent membrane transporters for various drugs and anions, with some such as MRP1 also utilising glutathione [28, 29].

The most intriguing characteristic distinguishing MDR proteins from other mammalian transporters is their highly promiscuous substrate specificity [30]. In 
contrast with selective (classical) transport proteins, multidrug transporters, as well as handling unique compounds, translocate a large number of structurally diverse mainly hydrophobic compounds, which explains the cross-resistance to several chemically unrelated compounds, the hallmark of the MDR phenotype [16-19]. Tumours with MDR protein overexpression, such as hepatomas, lung or colon carcinomas, frequently show intrinsic resistance. P-gp transports large hydrophobic, uncharged or slightly positively charged compounds, while the MRP family is the main transport vehicle for hydrophobic anionic conjugates and extrudes uncharged hydrophobic drugs. Table 1 is a list of commonly used drugs, including important anticancer agents, which are extruded by P-gp.

The precise physiological function of P-gp in the absence of therapeutics or toxins is probably a protective role. Results of gene knockout experiments in mice support the idea that MDR proteins play a part in protecting the cell from xenobiotics [31]. Tissue distribution of MDR-ABC proteins is quite varied. P-gp is often difficult to detect because of its low level of expression, but it is ubiquitous in those tissues involved in absorption and secretion [16-19] (e.g. epithelial cells of the kidney proximal tubules, superficial columnar epithelial cells of the colon and jejunum, hepatocytes, epithelial cells of pancreatic small ductules, adrenal medulla and cortex) [32] and in a variety of immune cells [33-36] where it probably contributes significantly to the removal of drugs and toxins from the bone marrow. Its expression varies between individuals and is a function of both genotypic characteristics and of general metabolic/environmental conditions, which may include exposure to heat shock, irradiation, genotoxic stress and inflammatory stimuli as well as cytokines and growth factors. It has been shown that P-gp-mediated drug transport can be stimulated by the antihypertensive prazosin and by progesterone [37].

The promise of preclinical data on the role of P-gp has been somewhat disappointing in terms of the clinical experience with P-gp modulators to overcome drug resistance [38]. Although P-gp appears to play a very important role in the CNS penetration of drugs, its effect on drug absorption may not be as important as generally believed [39]. In some studies, P-gp has been reported to have prognostic significance in certain types of neoplasms [40-42], but very often it has generally failed to show a correlation with clinical response [43-45]. This has led to much controversy regarding the precise role of P-gp in clinically relevant tumour drug resistance. Its precise mode of action also remains a perplexing problem. There
Table 1. Selected list of drugs that are extruded by P-gp

\begin{tabular}{lc}
\hline Cancer drugs & HIV protease inhibitors \\
Doxorubicin & Amprenavir \\
Daunorubicin & Indinavir \\
Vinblastine & Nelfinavir \\
Vincristine & Ritonavir \\
Actinomycin D & Saquinavir \\
Paclitaxel & Cardiac drugs \\
Teniposide & Digoxin \\
Etoposide & Quinidine \\
Immunosuppressive drugs & Anti-emetic \\
Cyclosporin A & Ondansetron \\
FK506 & Antidiarrhoeal agent \\
Lipid-lowering agent & Loperamide \\
Lovastatin & Antigout agent \\
Antihistamine & Colchicine \\
Terfenadine & Antibiotic \\
Steroids & Erythromycin \\
Aldosterone & Antihelminthic agent \\
Hydrocortisone & Ivermectin \\
Cortisol & Antituberculous agent \\
Corticosterone & Rifampin \\
Dexamethasone & Fluorescent dye \\
Dopamine antagonist & Rhodamine-123 \\
Domperidone &
\end{tabular}

have been suggestions that the MDR proteins do not transport drugs per se but alter ion transport or signal transduction, which then affects drug distribution [46].

Anticancer drugs and cytotoxic cytokines such as members of the TNF/Fas ligand family play a predominant role in apoptosis induction in tumour cells and are critical in cancer therapy. Given the wide-ranging actions of P-gp, one group has extensively examined its association with cell death [47]. Pathways leading to apoptosis appear to involve a family of cysteine aspases known as caspases [48]. Using drug-resistant tumour cell lines, their results suggest that $\mathrm{P}$-gp confers resistance to Fas-induced caspase- 3 activation and apoptosis. P-gp-expressing cells are resistant to a wide range of stimuli that activate the caspase apoptotic cascade, but are not resistant to caspase-independent cell death mediated by pore-forming proteins and GzB. Inhibition of P-gp with antibody inhibitors completely reverses the resistance to caspase-dependent cell death $[49,50]$. They also demonstrated ATPdependent inhibition of Fas-induced caspase- 8 activation but not formation of the death-inducing signal complex [51]. Cullen et al. [52], however, found that an MRP-overexpressing MDR leukaemia subline had the same level of Fas expression as the parental cells and sim- 
ilar apoptotic responses to anti-Fas antibody, questioning the hypothesis that selection of drug resistance results in resistance to Fas-mediated apoptosis.

\section{Genetic Responses}

Drugs such as methotrexate inhibit key enzymes in pathways controlling proliferation. Thus, increased transcription of the gene that encodes the enzyme can lead to increased levels of the target. As the drug concentration will be limited, it will be unable to block the additional enzyme that is being synthesised, and therefore the cell will effectively overcome the inhibitory effect. One manner in which expression can be elevated is through the process of gene amplification, which involves selective replication of a region of the chromosome, resulting in multiple copies of the same gene, with each one being transcribed to produce a high level of mRNA.

P-gp activity is also related to the status and level of activity of the MDR1 gene. Rifampicin can induce MDR 1 expression. Induction of intestinal P-gp by rifampicin has been shown to be the major mechanism responsible for reduced digoxin levels during concomitant rifampicin therapy; in healthy male volunteers, the oral bio-availability of digoxin decreased by $30 \%$ and intestinal P-gp levels were induced 3.5-fold during rifampicin therapy $[53,54]$.

Mickley et al. [55] found that in several drug-resistant cancer cell lines as well as in DNA from two leukaemic patients who had developed drug resistance, gene rearrangements had occurred resulting in initial activation or increased expression of MDR1. Polymorphism in exon 26 (C3435T) of MDR1 is significantly correlated with levels of expression and function of MDR1 [56]. Thus, gene amplifications/rearrangements, rifampicin induction and probably other factors can cause MDR1 overexpression.

Defects in the apoptotic pathway might constitute an alternative mode of therapy resistance [57]. The p53 protein is an important regulator of the cell cycle and is sensitive to any DNA damage (genotoxic stress) caused during replication, in which case it will normally induce G1 arrest and/or apoptosis to prevent the production of defective cells. Drugs, which increase DNA damage, will therefore lead to p53-mediated cell death. Mutations in this gene are frequently observed in human cancers; loss of $\mathrm{p} 53$ function will allow cells with damaged DNA to continue replicating, which means resistance to DNAdamaging drugs. From a trial of ovarian carcinoma, Petty et al. [58] concluded that enhanced genomic instability due to p53 inactivation might increase the likelihood of development of resistance to CTX over time. In a variety of tumours, p53 deletion was reported to be associated with MDR [59]. Inactivated p53 almost completely suppressed the induction of apoptosis or severely delayed it. Johnson and Fan [60] found that reduced expression of p53 in human breast cancer cells modified response to paclitaxel and 5-FU. It has been suggested that reactivation of mutant p53 may be an effective way of inducing tumour cell death [61]. Susceptibility of tumour cells to programmed cell death is influenced by a series of protooncogenes and tumour suppressor genes. Other genes, such as h-ras and bcl-2/bax, involved in the apoptotic pathway, have also been implicated in resistance [62]. This type of resistance will affect a wider range (possibly all) of anticancer drugs. It also potentially increases the proportion of surviving mutant cells, which leads to greater tumour heterogeneity.

\section{Enhanced DNA Repair}

Another way that cells can become resistant, for example to cisplatin, is by developing an enhanced ability to remove cisplatin-DNA adducts and to repair cisplatininduced lesions, through the action of DNA repair proteins. Levels of a nuclear protein called XPE-BF (xeroderma pigmentosum group $\mathrm{E}$ binding factor) were found to increase early in the development of cisplatin resistance. Excision repair cross-complementing protein (ERCC1) [63], most likely a DNA-binding protein, is another example of a DNA repair protein that may be involved in recognition of cisplatin damage; its expression is elevated in cisplatin-resistant cells compared with that in cells sensitive to cisplatin. The level of ERCC1 has been reported to increase as tumours become resistant to carboplatin [64]. Cross-resistance to carboplatin but not so much to either oxaliplatin or tetraplatin has been observed in cisplatin-resistant cells [65], so there are opportunities for second-line therapy. Resistance in non-seminomatous germ cell cancer cell lines was 1.7 - to 2.2 -fold with oxaliplatin compared to 3.9- to 6.1-fold with cisplatin [66].

\section{Alterations in Target Molecules}

It is possible that during the course of therapy, the target of that therapy could be modified in some way or even decrease to a level where it ceases to have any significant cellular influence and is therefore no longer a useful target to block. A fairly common example of this is encountered with anti-oestrogen (e.g. tamoxifen) therapy of breast cancer. Patients often undergo transition to an endocrine-resistant, from an initially responsive state, in which there 
is an apparent loss of oestrogen receptors in the resistant tumour cells. These patients no longer respond to tamoxifen treatment; however, their tumours can still, temporarily at least, be growth inhibited by inhibitors of oestrogen synthesis such as aromatase inhibitors [67, 68]. This is followed by a state of complete unresponsiveness to any endocrine manipulation. Presumably, the surviving cancer cells are no longer dependent on oestrogen for growth and continued attempts to block the now diminished original target, i.e. the oestrogen receptor, are fruitless.

Gene mutations are common in cancer cells; indeed it is this phenomenon, which gives that cell its remarkable properties. Cytotoxic drugs are aimed at disabling a component whose continued function is necessary for cell survival; cells that survive the treatment may do so by carrying a gene, for that target, which has mutated in such a way that it produces a protein that retains its activity but no longer binds to the drug, for stereochemical reasons, and is therefore not inhibited by it. The result is a functioning cell resistant to the drug. Resistance to the herbicide, glyphosate, can be induced in plants by transfection with a mutated aroA gene which encodes an enzyme necessary for synthesis of aromatic amino acids. The modified enzyme retains its essential catalytic activity but no longer binds glyphosate. Imatinib (Gleevac; STI571) is a tyrosine kinase inhibitor that induces apoptosis by preventing cell growth in cancerous cells by disabling the damaged bcr-abl receptors, preventing ATP binding. In clinical trials treating chronic myeloid leukaemia with STI571, Gorre et al. [69] found that patients in remission had reactivated bcr-abl activity; 3 of the 11 patients had amplified copies of the oncogenic bcr-abl gene. Two thirds of patients tested harboured a single-point mutation within the ATP-binding site of bcr-abl. Thus, the bcr-abl gene appears important in both the initiation and the maintenance of tumourigenicity. Identifying mutated alleles may help to detect drug-resistant clones prior to clinical relapse.

Topoisomerase, because of its vital role in DNA replication, is a favourite target for CTX. Mutations in this protein, which alter its nuclear localisation, render those cells insensitive to drugs such as etoposide designed to block the activity of topoisomerase II.

Target molecules may also disappear from cancer cells as a result of the loss of the corresponding gene. Chromosomal losses are a common feature of cancer. Duesberg et al. [70, 71] have suggested that it is the aneuploid nature of cancer cells that best explains the development of MDR. They conclude that the cause of this resistance is not simply the loss of drug-sensitive genes when a chro- mosome is lost, which can happen frequently given the large number of cells undergoing division in a tumour. Chromosome reassortment during mitosis is also capable of activating/inactivating numerous biochemical pathways that could disarm a variety of drugs. By contrast, the chances for a normal cell to lose or gain a chromosome during mitosis are undetectably low under most conditions and hence, it is not usual to see resistance to CTX in normal cells.

Penetration of drugs to their intended site of action is also a problem that is encountered and must be regarded as a form of resistance. The central portion of large tumours tends to have a poor blood supply and drugs will have limited access to this area. Therefore, CTX is more effective for smaller tumours and becomes less so as the tumour becomes larger. Treatment of brain tumours also faces the problems posed by the blood-brain barrier. This is a dynamic network of vessels, which restrict movement of molecules into the CNS. Many drugs are ineffective because they cannot pass through this barrier. Others, which may initially have been able to penetrate inside, may later be blocked due to the dynamic nature of this resistance. P-gp is an important component of this barrier and is present in high concentration on the apical surface of the endothelial cells [72-74]. While it restricts access of various potentially harmful pharmacologic agents to the brain, it also poses a problem in the treatment of brain diseases. Increasing the concentration of the drug to achieve entry into the brain to circumvent the action of P-gp presents problems of systemic toxicity. Begley [75] has reviewed the role of $\mathrm{ABC}$ transporters.

Genetic variations in transporter and metabolic enzymes are associated with differences in drug absorption, distribution, metabolism and excretion and are considered to be the major determinants of interindividual variability. Cytochrome p450s (cyp450) are a group of enzymes that alter the chemical structure of drugs, for elimination. Most drugs that are P-gp substrates are also Cyp3A4 substrates. These enzymes are located in the cells of the intestinal wall, endothelium, liver and other tissues. Genetic differences in cyp450 structure and expression lead to functional differences in drug and nutrient absorption and clearance. Over 50 cyp450 genes are expressed in different tissues of the human body, with more than a thousand identified in all species [76]. CYP3A4 is the most abundantly expressed P450 in human liver and small intestine [77] and is known to metabolise more than 120 different drugs. Hepatic expression of CYP3A4 is known to vary by more than 50 -fold among individuals and in vivo CYP3A4 enzymatic function (drug clearance) 
varies by at least 20 -fold. The genetic basis for this was reviewed by Lamba et al. [78]. The combination of P-gp and cyp450 largely determines drug absorption and biodistribution to tissues, limiting intestinal transcellular permeability, biliary disposition in hepatocytes, urinary elimination through the renal epithelium and placental transport. In 2003, Roche Diagnostics launched the Amplichip CYP450, the first pharmacogenomic micro-array for clinical applications. This tests for variants of cyp2D6, as this is missing in 7\% of Caucasians and 2\% of nonCaucasians. CYP2D6 is also hyperactive in 30\% of East Africans. Therefore, CYP2D6 testing is considered more important than CYP3A as its expression varies more from one person to the next.

\section{Metabolic Effects}

Xenobiotics often modify high-density apolipoprotein. The result of this is to enhance hepatic drug elimination, reducing its effective plasma concentration. Another physiological response to the presence of drugs is the overexpression of drug-metabolising enzymes or carrier molecules; e.g. the increased production of glutathione [79] or ubiquitin contributes to inactivation of the drug by forming conjugates that are excreted. Resistance to cisplatin in ovarian carcinoma cells is associated with increased expression of dihydrodiol dehydrogenase [80]. In other cases, underexpression of drug-metabolising enzymes can reduce drug efficacy in situations where an administered inactive prodrug has to undergo catalytic conversion to an active form. Thus, arabinoside is required to be activated by the action of deoxycytidine kinase; loss or mutation of this enzyme will render this drug less effective [81].

Protein kinase $\mathrm{C}$ also plays an important role in both drug exclusion and apoptosis [82]. There are 12 or more different isoforms of this enzyme, which may regulate different cellular phosphorylation events. Drug-resistant breast cancer cells can have elevated activity, but the role of particular isoforms is undetermined.

Studies on breast cancer cells have also suggested involvement of the extracellular matrix in drug resistance [83]. It is known that apoptosis can be mediated by activation of the Fas/Fas-L pathway. These authors showed that ligation of $b 1$ integrins by their extracellular matrix ligands inhibits apoptosis mediated by paclitaxel and vincristine, which activate this pathway. These agents act by causing release of mitochondrial cytochrome c. Integrinmediated protection from the drug-induced apoptosis and inhibition of cytochrome $\mathrm{c}$ release were dependent on the activation of the PI 3 kinase/Akt pathway.

\section{Growth Factors}

Serum levels of interleukin (IL)-6 have been found to be elevated in patients with various types of cancer. Conze et al. [84] demonstrated that autocrine production of IL- 6 by breast cancer cells could promote resistance to CTX. Cells sensitive to the CTX did not express appreciable IL-6, whereas high levels were detectable in multidrug-resistant cells. The mechanism of this resistance was attributed to the activation of the CCAAT enhancerbinding protein family of transcription factors and induction of MDR1 gene expression. They suggested that as some breast tumours contain IL-6-producing cells, this might have potential as a factor for predicting CTX resistance.

Song et al. [85] have shown that chemoresistance may be induced by extracellular factors in tumour-bearing organs. Comparing chemosensitivity and proteins in different tumours and different culture systems, they found elevated levels of acidic and basic fibroblast growth factors in the media of solid and metastatic tumours. These conditioned media induced broad-spectrum resistance to drugs (paclitaxel, doxorubicin and 5-FU) with diverse structures and mechanisms of action. Application in combination, of these two growth factors, could produce a 10-fold increase in drug resistance, whereas suramin, a known inhibitor of fibroblast growth factors, was able to reverse this resistance.

\section{Drug Resistance Testing}

Not all patients are necessarily resistant to CTX. Some tumours may be highly resistant to most cytotoxic drugs, while others may be quite sensitive. Therefore, it would be useful to have some tests, which could predict resistance and subsequent clinical failure. This would spare patients from the trauma of ineffective CTX. A company called IMPATH (Los Angeles, Calif., USA) has developed a cell culture drug resistance assay, which they claim can help in the selection of chemotherapeutic agents that have the greatest likelihood of being clinically effective. Their method essentially measures ${ }^{3} \mathrm{H}$-thymidine uptake into cultured tumour cells, taken from fresh biopsy specimens, in the presence of various drugs; an algorithm applied to the data is used to determine the probability that a patient will respond to the various therapies tested in the assay. Kern and Weisenthal [86] reported that this assay used in clinical trials was highly accurate in demonstrating that cells extremely resistant in vitro were also resistant in vivo. The usefulness of such in vitro testing 
however remains a controversial matter and oncologists still prefer to rely on experience and the results of clinical trials with the drug. There has been much discussion on the subject [87].

\section{Approaches to Overcoming Drug Resistance}

As the mechanisms responsible for drug resistance become clearer, several strategies for countering this phenomenon are beginning to emerge. The most obvious response, and the one most widely employed, is to use combination drug therapy. The general rationale for choosing which drugs to combine is to use drugs which are active against the tumour when used individually; to combine drugs that have different modes and sites of action to produce complementary/synergistic rather than just additive effect; to combine drugs with minimally overlapping toxicities, allowing administration of maximally effective doses of each active agent to optimally schedule each drug, and to use drugs with narrowest possible cycle intervals necessary for bone marrow recovery. Drugs that are typically used in combination therapy for breast cancer are listed in table 2.

High-dose CTX can destroy the tumour cells before they have the opportunity to form resistant colonies, but this often comes at too great a cost to the patient. Less severe strategies are needed. As the action of the ABC transporters is thought the most significant reason for resistance, they have received the most attention. A large number of drugs have been identified that are pharmacological antagonists of particularly the P-gp. These include a variety of quite distinct groups of compounds, some of which are listed in table 3 . Used in conjunction with the cytotoxic drugs already mentioned, these can potentiate their effects by allowing those drugs to remain in the target cells longer. These agents may be more properly regarded as modulators or reversing agents as even those that appear to be inhibitors of drug efflux may themselves be substrates, in so far as they can stimulate ATPase activity. The use of these in combination can subvert the cell's defence. For example, P-gp blocks absorption in the gut and may be considered part of the 'first pass effect'; it can act as a 'gatekeeper' for subsequent P450 cytochrome action. If one drug is a substrate of both P-gp and the cytochrome P450 subfamily IIIA (nifedipine oxidase) polypeptide 4 (CYP3A4; found in close proximity in the intestinal mucosa), and a second drug is added that is a modulator (e.g. erythromycin, mibefradil, ketoconazole), then the first drug will be al-
Table 2. Selected adjuvant CTX drug combinations used for breast cancer treatment

\begin{tabular}{|c|c|}
\hline $\mathrm{CMF}$ & Cyclophosphamide, methotrexate, 5-FU \\
\hline $\mathrm{AC}$ & Doxorubicin, cyclophosphamide \\
\hline CAF & Cyclophosphamide, doxorubicin, 5-FU \\
\hline $\mathrm{AC} \rightarrow \mathrm{T}$ & Doxorubicin, cyclophosphamide, paclitaxel \\
\hline CEF & Cyclophosphamide, epirubicin, 5-FU \\
\hline CMFVP & $\begin{array}{l}\text { Cyclophosphamide, methotrexate, } 5 \text {-FU, } \\
\text { vincristine, prednisone }\end{array}$ \\
\hline AT & Doxorubicin, docetaxel (Taxotere) \\
\hline $\mathrm{AC} \rightarrow$ Taxoter & Doxorubicin, cyclophosphamide, docetaxel \\
\hline
\end{tabular}

Table 3. Selected list of drugs that modulate P-gp

Immunosuppressant
Cyclosporin A
Valspodar (PSC833)
HIV protease inhibitors
Ritonavir
Saquinavir
Nelfinavir
Calcium channel blocker
Verapamil
Progesterone antagonist
Mifepristone (RU486)
Anti-oestrogen
Tamoxifen

Anti-arrhythmic agent Quinidine

Antifungal agent Ketoconazole Sedative Midazolam Acridone carboxamide GG918 (GF120918)

Peptide chemosensitiser Reversin 121

Reversin 205

lowed to increase its intracellular accumulation as a result of inhibition of the P-gp blockade. Since CYP3A4 is also inhibited, unmetabolised drug will enter the circulation. Another example is the entry of the antidiarrhoeal, loperamide, into the CNS (from which it is normally excluded) by the simultaneous administration of the P-gp modulator, quinidine [88]. The use of P-gp inhibitors may lead to undesirable consequences. Thus, the simultaneous use of cytotoxic drugs and agents that block P-gp function has raised questions of safety. In knockout mice with a genetic disruption of the mdrla P-gp, much higher levels of substrate drugs accumulated in the brain, with markedly slower elimination from the circulation, resulting in dramatically increased toxicity to normal tissue [89].

Another mode of MDR reversal utilises monoclonal antibodies, several of which inhibit P-gp-mediated drug efflux in vitro [90, 91]. For in vivo applications, compa- 
nies such as Immunomedics Inc. are developing polyspecific antibodies targeting both MDR protein and cancer epitopes. These antibodies may also be conjugated to cytotoxins, which can be internalised.

Various other means of circumventing resistance that are being explored are based on experimental observations described above: these include adjuvant treatment with suramin to reverse fibroblast growth factor-mediated resistance [85]; inhibition of p13 kinase/Akt to prevent resistance mediated through integrin involvement, and re-expression of wild-type tumour suppressor genes.

There have also been considerable technological advances that have allowed the identification of genes, which are potentially responsible for drug resistance, which had not been recognised previously using traditional approaches. Differential or subtractive analyses of gene expression in drug-sensitive and drug-resistant cell lines or tumours can now be performed with cDNA chip micro-arrays. This may facilitate identification of drug response genes whose expression is altered by the drug, and of signaling and metabolic pathways involved in drug activity.

More recent innovations to inhibit MDR proteins include transcriptional/translational inhibition through the introduction of antisense oligonucleotides or ribozymes $[92,93]$. Interference [94] is another approach to knock out specific mRNAs and is rapidly gaining popularity; MDR genes would represent a good target. However, as many of these methods require gene targeting and transfer, they are unlikely to produce any really significant in vivo applications anytime soon, despite considerable progress in the general approach using animal models.

A more immediate strategy, termed 'metronomic dosing', is to simultaneously target the associated endothelial cells [95], which support tumour cell growth. This involves combining anti-angiogenic drugs with a more frequent regimen of cytotoxic agents; endothelial cells are more susceptible to CTX and a lower dose of CTX agents can be used, resulting in reduced side-effects [96]. Experiments in tumour-bearing mice have shown that administration of DC101, a blocker of vascular endothelial growth factor, and a submaximal tolerated dose of vinblastine induced effective tumour regression. Given individually, both agents were ineffective [97].

Targeting of growth factor receptors, which are overexpressed in breast cancer, with antibodies has been successfully employed for reducing tumour burden. The prime example of this is the use of trastuzumab aimed against the HER2 protein [98]. Cetuximab is another antibody that specifically blocks the epidermal growth fac- tor receptor (EGFR), which is overexpressed in several cancers, particularly of the GI tract [99-101]. It has been successfully used in patients who were refractory to treatment with fluorouracil and irinotecan $[102,103]$. The effectiveness of the combination of irinotecan and cetuximab in patients with irinotecan-refractory tumours [104] suggests that cetuximab may circumvent irinotecan resistance. These authors suggested that EGFR inhibition by cetuximab may overcome this resistance by abrogating drug efflux [105-109], restoring apoptosis [110] or impairing DNA repair activity $[111,112]$. However, the efficacy of cetuximab may not be related just to the overall level of EGFR in the tumour, but perhaps to its phosphorylation state [113].

Anti-angiogenic agents such as bevacizumab, a humanized monoclonal antibody against VEGF, are also effective for metastatic colorectal cancer given in combination with irinotecan, fluorouracil and leucovorin [114]. It is suggested that in this case bevacizumab may improve delivery of CTX by altering tumour vasculature and decreasing the elevated interstitial pressure in tumours $[115,116]$.

\section{Putting Resistance to Good Use}

One of the major problems with CTX is its unwanted toxicity on bone marrow. Although this tissue recovers after cessation of treatment, the patient is severely immune compromised and has to be given additional protective treatment. The phenomenon of drug resistance could be turned to advantage for the patient's benefit. Stem cells taken from the patient could be transduced with a retroviral construct containing an MDR gene and used to repopulate the bone marrow, conferring resistance against subsequent exposure to CTX [93, 117]. Knockout experiments in mice have demonstrated targeted disruption of the MDR1b gene [118]. Several clinical trials are examining the possibility of delivering MDR1 gene-expressing vectors into cancer patients to induce chemoprotection or for in vivo selection of regenerating stem cells. Preliminary results seem to indicate that only modest levels of protection can be achieved in vivo, due to the very low percentages of patients' cells expressing MDR1 following hematopoietic reconstitution [119].

The old adage that prevention is better than cure applies as much to this situation. A concerted effort should be made to identify factors that can predict the onset of resistance before its clinical manifestation. This could al- 
low the physician valuable lead time to alter either the combination of cytotoxic drugs or the form of the therapy. Attempts to devise methods of early detection of metastatic relapse have concentrated mainly on the development of very sensitive molecular assays for the detection of tumour-associated genes/proteins in circulating cells in the blood or micrometastases in the bone marrow [120 122]. The continual monitoring of cancer patients on therapy, for the traditional tumour markers such as carcino-embryonic antigen, has proved of limited use except in a few cancers; e.g. bHCG is a good indicator of early relapse in choriocarcinomas. The absence of a clearly defined molecule that is produced or is present only in can- cer cells has greatly hindered these efforts. For the common adenocarcinomas, epithelial cell markers have been investigated on the premise that such cells are normally absent from blood, and if they appear in cancer patients, they must originate from a growing tumour. Without this early warning system, the problem of overcoming development of chemoresistance is quite considerable. In an ideal situation, therapy would be tailored to suit the individual at the outset; this is unlikely at least for the very near future, despite rapid progress in pharmacogenomics. In the meantime, a better understanding of the mechanisms of resistance will at least allow the physician to modulate the therapy on a need to do basis.

\section{References}

-1 Roskoski R Jr: The ErbB/HER receptor protein-tyrosine kinases and cancer. Biochem Biophys Res Commun 2004;319:1-11.

$\checkmark 2$ Gross ME, Shazer RL, Agus DB: Targeting the HER-kinase axis in cancer. Semin Oncol 2004; 31:9-20.

-3 Finn RS, Slamon DJ: Monoclonal antibody therapy for breast cancer: Herceptin. Cancer Chemother Biol Response Modif 2003;21: 223-233.

-4 Herbst RS: Review of epidermal growth factor receptor biology. Int J Radiat Oncol Biol Phys 2004;59:21-26.

$>5$ Gruner BA, Weitman SD: The folate receptor as a potential therapeutic anticancer target. Invest New Drugs 1999;16:205-219.

$\checkmark 6$ Reddy JA, Low PS: Folate-mediated targeting of therapeutic and imaging agents to cancers. Crit Rev Ther Drug Carrier Syst 1998;15:587627.

77 Zamble DB, Lippard SJ: Cisplatin and DNA repair in cancer chemotherapy. Trends Biochem Sci 1995;20:435-439.

$>8$ Hurley LH: DNA and its associated processes as targets for cancer therapy. Nat Rev Cancer 2002;2:188-200.

-9 Kast C, Gros P: Topology mapping of the amino-terminal half of multidrug resistance-associated protein by epitope insertion and immunofluorescence. J Biol Chem 1997;272: 26479-26487.

10 Kast C, Gros P: Epitope insertion favors a six transmembrane domain model for the carboxy-terminal portion of the multidrug resistance-associated protein. Biochemistry 1998; 37:2305-2313.

11 Dean M, Rzhetsky A, Allikmets R: The human ATP-binding cassette (ABC) transporter superfamily. Genome Res 2001;11:1156-1166.

$\checkmark 12$ Juliano RL, Ling V: A surface glycoprotein modulating drug permeability in Chinese hamster ovary cell mutants. Biochim Biophys Acta 1976;455:152-162.
13 Chen CJ, Chin JE, Ueda K, Clark DP, Pastan I, Gottesman MM, Roninson IB: Internal duplication and homology with bacterial transport proteins in the mdr 1 (P-glycoprotein) gene from multidrug-resistant human cells. Cell 1986;47:381-389.

14 Ueda K, Cardarelli C, Gottesman MM, Pastan I: Expression of a full-length cDNA for the human 'MDR1' gene confers resistance to colchicine, doxorubicin, and vinblastine. Proc Natl Acad Sci USA 1987;84:3004-3008.

15 Gottesman MM, Hrycyna CA, Schoenlein PV, Germann UA, Pastan I: Genetic analysis of the multidrug transporter. Annu Rev Genet 1995 29:607-643.

16 Endicott JA, Ling V: The biochemistry of Pglycoprotein-mediated multidrug resistance. Ann Rev Biochem 1989;58:137-171.

17 Higgins CF: ABC transporters: From microorganisms to man. Annu Rev Cell Biol 1992;8: 67-113.

18 Gottesman MM, Pastan I, Ambudkar SV: Pglycoprotein and multidrug resistance. Curr Opin Genet Dev 1996;6:610-617.

19 Gottesman MM, Fojo T, Bates SE: Multidrug resistance in cancer: Role of ATP-dependent transporters. Nat Rev Cancer 2002;2:48-58.

20 Cole SP, Bhardwaj G, Gerlach JH, Mackie JE, Grant CE, Almquist KC, Stewart AJ, Kurz EU, Duncan AM, Deeley RG: Over-expression of a transporter gene in a multidrug-resistant human lung cancer cell line. Science 1992;258: 1650-1654.

21 Borst P, Evers R, Kool M, Wijnholds J: A family of drug transporters: The multidrug resistance-associated proteins. J Natl Cancer Inst 2000;92:1295-1302.

22 Cole SP, Deeley RG: Multidrug resistance mediated by the ATP-binding cassette transporter protein MRP. Bioessays 1998;20:931-940.

23 Litman T, Druley TE, Stein WD, Bates SE: From MDR to MXR: New understanding of multidrug resistance systems, their properties and clinical significance. Cell Mol Life Sci 2001;58:931-959.
24 Lecureur V, Sun D, Hargrove P, Schuetz EG, Kim RB, Lan LB, Schuetz JD: Cloning and expression of murine sister of P-glycoprotein reveals a more discriminating transporter than MDR1/P-glycoprotein. Mol Pharmacol 2000: 57:24-35

-25 Smith AJ, van Helvoort A, van Meer G, Szabo K, Welker E, Szakacs G, Varadi A, Sarkadi B, Borst P: MDR3 P-glycoprotein, a phosphatidylcholine translocase, transports several cytotoxic drugs and directly interacts with drugs as judged by interference with nucleotide trap ping. J Biol Chem 2000;275:23530-23539.

-26 Kool M, van der Inden M, de Haas M, Baas F, Borst P: Expression of human MRP6, a homologue of the multidrug resistance protein gene MRP1, in tissues and cancer cells. Cancer Res 1997;57:3537-3547.

27 Nooter K, Westerman AM, Flens MJ, Zaman GJ, Scheper RJ, van Wingerden KE, Burger H, Oostrum R, Boersma T, Sonneveld P: Expression of the multidrug resistance-associated protein (MRP) gene in human cancers. Clin Cancer Res 1995;111:1301-1310.

28 Homolya L, Varadi A, Sarkadi B: Multidrug resistance-associated proteins: Export pumps for conjugates with glutathione, glucoronate or sulfate. Biofactors 2003; 17:103-114.

29 Haimeur A, Conseil G, Deeley RG, Cole SP: The MRP-related and BCRP/ABCG2 multidrug resistance proteins: Biology, substrate specificity and regulation. Curr Drug Metab 2004;5:21-53.

30 Zaman GJ, Lankelma J, van Tellingen O, Beijnen J, Dekker H, Paulusma C, Oude Elferink RP, Baas F, Borst P: Role of glutathione in the export of compounds from cells by the multidrug-resistance-associated protein. Proc Natl Acad Sci USA 1995;92:76907694.

31 Schinkel, AH: The physiological function of drug-transporting P-glycoproteins. Semin Cancer Biol 1997;8:161-170. 
-32 Thiebaut F, Tsuruo T, Hamada H, Gottesman MM, Pastan I, Willingham MC: Cellular localization of the multidrug-resistance gene product P-glycoprotein in normal human tissues. Proc Natl Acad Sci USA 1987;84:7735-7738.

-33 Klimecki WT, Futscher BW, Grogan TM, Dalton WS: P-glycoprotein expression and function in circulating blood cells from normal volunteers. Blood 1994;83:2451-2458.

-34 Gottesman MM, Pastan I, Ambudkar SV: Pglycoprotein and multidrug resistance. Curr Opin Genet Dev 1996;6:610-617.

-35 Johnstone RW, Ruefli AA, Smyth MJ: Multiple physiological functions for multidrug transporter P-glycoprotein? Trends Biochem Sci 2000;25:1-6.

-36 Johnstone RW, Ruefli AA, Tainton KM, Smyth MJ: A role for P-glycoprotein in regulating cell death. Leuk Lymphoma 2000;38:111.

>37 Shapiro AB, Fox K, Lam P, Ling V: Stimulation of P-glycoprotein-mediated drug transport by prazosin and progesterone. Evidence for a third drug-binding site. Eur J Biochem 1999;259:841-850.

38 Sikic BI, Fisher GA, Lum BA, Halsey J, Beketic-Oreskovic L, Chen G: Modulation and prevention of multidrug resistance by inhibitors of P-glycoprotein. Cancer Chemother Pharmacol 1997;40(suppl):S13-S19.

-39 Lin JH, Yamazaki M: Clinical relevance of Pglycoprotein in drug therapy. Drug Metab Rev 2003;35:417-454

40 Penson RT, Oliva E, Skates SJ, Glyptis T, Fuller AF Jr, Goodman A, Seiden MV: Expression of multidrug resistance- 1 protein inversely correlates with paclitaxel response and survival in ovarian cancer patients: A study in serial samples. Gynecol Oncol 2004;93:98-106.

-41 van den Heuvel-Eibrink MM, Sonneveld P, Pieters R: The prognostic significance of membrane transport-associated multidrug resistance (MDR) proteins in leukemia. Int $\mathrm{J}$ Clin Pharmacol Ther 2000;38:94-110.

$\checkmark 42$ Wuchter C, Leonid K, Ruppert V, Schrappe M, Buchner T, Schoch C, Haferlach T, Harbott J, Ratei R, Dorken B, Ludwig WD: Clinical significance of P-glycoprotein expression and function for response to induction chemotherapy, relapse rate and overall survival in acute leukemia. Haematologica 2000;85:711-721.

-43 Consoli U, Santonocito A, Stagno F, Fiumara P, Privitera A, Parisi G, Giustolisi GM, Pavone B, Palumbo GA, Di Raimondo F, Milone G, Guglielmo P, Giustolisi R: Multidrug resistance mechanisms in chronic lymphocytic leukaemia. Br J Haematol 2002;116:774-780.

-44 Kumta SM, Zhu QS, Lee KM, Griffith J, Chow LT, Leung PC: Clinical significance of P-glycoprotein immunohistochemistry and doxorubicin binding assay in patients with osteosarcoma. Int Orthop 2001;25:279-282.

$\checkmark 45$ Leonessa F, Clarke R: ATP binding cassette transporters and drug resistance in breast cancer. Endocr Relat Cancer 2003;10:43-73.

-46 Roepe PD: What is the precise role of human MDR 1 protein in chemotherapeutic drug resistance? Curr Pharm Des 2000;6:241-60.
47 Smyth MJ, Krasovskis E, Sutton VR, Johnstone RW: The drug efflux protein, P-glycoprotein, additionally protects drug-resistant tumor cells from multiple forms of caspase-dependent apoptosis. Proc Natl Acad Sci USA 1998 12:7024-7029.

48 Henkart PA: ICE family proteases: Mediators of all apoptotic cell death? Immunity 1996;4: 195-201.

49 Johnstone RW, Cretney E, Smyth MJ: P-glycoprotein protects leukemia cells against caspasedependent, but not caspase-independent, cell death. Blood 1999;93:1075-1085.

50 Ruefli AA, Smyth MJ, Johnstone RW: HMBA induces activation of a caspase-independent cell death pathway to overcome P-glycoprotein-mediated multidrug resistance. Blood 2000;95:2378-2385.

51 Ruefli AA, Tainton KM, Darcy PK, Smyth MJ, Johnstone RW: P-glycoprotein inhibits caspase- 8 activation but not formation of the death inducing signal complex (disc) following Fas ligation. Cell Death Differ 2002;9:12661272.

52 Cullen KV, Davey RA, Davey MW: Drug resistance does not correlate with resistance to Fas-mediated apoptosis. Leuk Res 2001;25: 69-75.

53 Fromm MF, Kauffmann HM, Fritz P, Burk O, Kroemer HK, Warzok RW, Eichelbaum M, Siegmund W, Schrenk D: The effect of rifampin treatment on intestinal expression of human MRP transporters. Am J Pathol 2000 157:1575-1580.

54 Greiner B, Eichelbaum M, Fritz P, Kreichgauer HP, von Richter O, Zundler J, Kroemer HK The role of intestinal P-glycoprotein in the interaction of digoxin and rifampin. J Clin Invest 1999; 104:147-153.

55 Mickley LA, Spengler BA, Knutsen TA, Biedler JL, Fojo T: Gene rearrangement: A novel mechanism for MDR-1 gene activation. J Clin Invest 1997;99:1947-1957.

56 Hoffmeyer S, Burk O, von Richter O, Arnold HP, Brockmoller J, Johne A, Cascorbi I, Gerloff T, Roots I, Eichelbaum M, Brinkmann U: Functional polymorphisms of the human multidrug-resistance gene: Multiple sequence variations and correlation of one allele with P-glycoprotein expression and activity in vivo. Proc Natl Acad Sci USA 2000;97:3473-3478.

57 Dive C, Hickman JA: Drug-target interactions: Only the first step in the commitment to a programmed cell death? Br J Cancer 1991;64: 192-196.

58 Petty R, Evans A, Duncan I, Kurbacher C and Cree I: Drug resistance in ovarian cancer - The role of p53. Pathol Oncol Res 1998;4:97-102.

59 Grunicke H: Oncogenes and drug resistance. Deutsche Krebsgesellschaft e.V. Materials, 23rd Congr, Berlin, June 8-12, 1998

60 Johnson KR, Fan W: Reduced expression of p53 and p21WAF1/CIP1 sensitizes human breast cancer cells to paclitaxel and its combination with 5-fluorouracil. Anticancer Res 2002;22:3197-3204.
61 Selivanova G: Mutant p53: The loaded gun. Curr Opin Investig Drugs 2001;2:1136-1141.

62 Burger, H, Nooter K, Boersma AWM, Van Wingerden KE, Looijenga LHJ, Jochemsen AG, Stoter G: Distinct p53-independent apoptotic cell death signaling pathways in testicular germ cell tumour cell lines. Int J Cancer 1999; 81:629-628.

63 Rosell R, Taron M, Ariza A, Barnadas A, Mate JL, Reguart N, Margel M, Felip E, Mendez P, Garcia-Campelo R: Molecular predictors of response to chemotherapy in lung cancer. Semin Oncol 2004;31:20-27.

64 Chu G: Cellular responses to cisplatin. The roles of DNA-binding proteins and DNA repair. J Biol Chem 1994;269:787-790.

65 Rixe O, Ortuzar W, Alvarez M, Parker R, Reed E, Paull K, Fojo T: Oxaliplatin, tetraplatin, cisplatin, and carboplatin: Spectrum of activity indrug-resistant cell lines and in the cell lines of the National Cancer Institute's Anticancer Drug Screen panel. Biochem Pharmacol 1996; 52:1855-1865.

66 Dunn TA, Schmoll HJ, Grunwald V, Bokemeyer C, Casper J: Comparative cytotoxicity of oxaliplatin and cisplatin in non-seminomatous germ cell cancer cell lines. Invest New Drugs 1997;15:109-114.

67 Miller WR: Biological rationale for endocrine therapy in breast cancer. Best Pract Res Clin Endocrinol Metab 2004; 18:1-32.

68 Campos SM: Aromatase inhibitors for breast cancer in postmenopausal women. Oncologist 2004:9:126-136.

69 Gorre ME, Mohammed M, Ellwood K, Hsu N, Paquette R, Rao PN, Sawyers CL: Clinical resistance to STI-571 cancer therapy caused by BCR-ABL gene mutation or amplification. Science 2001;293:876-880.

70 Duesberg P, Stindl R, Hehlmann R: Explaining the high mutation rates of cancer cells to drug and multidrug resistance by chromosome re-assortments that are catalyzed by aneuploidy. Proc Natl Acad Sci USA 2000;97:1429514300.

71 Duesberg P, Stindl R, Hehlmann R: Origin of multidrug resistance in cells with and without multidrug resistance genes: Chromosome reassortments catalyzed by aneuploidy. Proc Natl Acad Sci USA 2001;98:11283-11288.

72 Ramakrishnan P: The role of P-glycoprotein in the blood-brain barrier. Einstein Q J Biol Med 2003;19:160-165.

73 Tatsuta T, Naito M, Oh-Hara T, Sugawara I, Tsuruo T: Functional involvement of P-glycoprotein in blood-brain barrier. J Biol Chem 1992;267:20383-20391.

74 Hughes CS, Vaden SL, Manaugh CA, Price GS, Hudson LC: Modulation of doxorubicin concentration by cyclosporin $\mathrm{A}$ in brain and testicular barrier tissues expressing P-glycoprotein in rats. J Neurooncol 1998;37:45-54

75 Begley DJ: ABC transporters and the bloodbrain barrier. Curr Pharm Des 2004;10:12951312.

76 Cytochrome CYP450 standardised nomenclature committee website: http://drnelson.utmem.edu/CytochromeP450.html. 
77 Waxman DJ: P450 gene induction by structurally diverse xenochemicals: Central role of nuclear receptors CAR, PXR, and PPAR. Arch Biochem Biophys 1999;369:11-23.

-78 Lamba JK, Lin YS, Schuetz EG, Thummel KE: Genetic contribution to variable human CYP3A-mediated metabolism. Adv Drug Deliv Rev 2002;54:1271-1294.

79 Gamcsik MP, Dubay GR, Cox BR: Increased rate of glutathione synthesis from cystine in drug-resistant MCF-7 cells. Biochem Pharmacol 2002;63:843-851.

-80 Deng HB, Parekh HK, Chow KC, Simpkins H: Increased expression of dihydrodiol dehydrogenase induces resistance to cisplatin in human ovarian carcinoma cells. J Biol Chem 2002; 277:15035-15043.

-81 Dumontet C, Fabianowska-Majewska K, Mantincic D, Callet Bauchu E, Tigaud I, Gandhi V, Lepoivre M, Peters GJ, Rolland MO, Wyczechowska D, Fang X, Gazzo S, Voorn DA, Vanier-Viornery A, MacKey J: Common resistance mechanisms to deoxynucleoside analogues in variants of the human erythroleukaemic line K562. Br J Haematol 1999; 106: $78-85$.

-82 Hofmann J: Protein kinase C isozymes as potential targets for anticancer therapy. Curr Cancer Drug Targets 2004;4:125-146.

$\checkmark 83$ Aoudjit F, Vuori K: Integrin signaling inhibits paclitaxel-induced apoptosis in breast cancer cells. Oncogene 2001;20:4995-5004.

-84 Conze D, Weiss L, Regen PS, Bhushan A, Weaver D, Johnson P, Rincon M: Autocrine production of interleukin 6 causes multidrug resistance in breast cancer cells. Cancer Res 2001;61:8851-8858.

-85 Song S, Wientjes MG, Gan Y, Au JL: Fibroblast growth factors: An epigenetic mechanism of broad spectrum resistance to anticancer drugs. Proc Natl Acad Sci USA 2000;97:86588663.

86 Kern DH, Weisenthal LM: Highly specific prediction of antineoplastic drug resistance with an in vitro assay using suprapharmacologic drug exposures. J Natl Cancer Inst 1990;82: 582-588.

\$ 87 McGuire WL, Kern DH, Von Hoff DD, Weisenthal LM: In vitro assays to predict drug sensitivity and drug resistance. A panel discussion. Breast Cancer Res Treat 1988;12:7-21.

88 Sadeque AJ, Wandel C, He H, Shah S, Wood AJ: Increased drug delivery to the brain by Pglycoprotein inhibition. Clin Pharmacol Ther 2000;68:231-237.

-89 Schinkel AH, Mol CA, Wagenaar E, van Deemter L, Smit JJ, Borst P: Multidrug resistance and the role of P-glycoprotein knockout mice. Eur J Cancer 1995;31A:1295-1298.

-90 Pearson JW, Fogler WE, Volker K, Usui N, Goldenberg SK, Gruys E, Riggs CW, Komschlies K, Wiltrout RH, Tsuruo T, et al: Reversal of drug resistance in a human colon cancer xenograft expressing MDR1 complementary DNA by in vivo administration of MRK-16 monoclonal antibody. J Natl Cancer Inst 1991; 83:1386-1391.
91 Mechetner EB, Roninson IB: Efficient inhibition of P-glycoprotein-mediated multidrug resistance with a monoclonal antibody. Proc Natl Acad Sci USA 1992;89:5824-5828.

-92 Pawlak W, Zolnierek J, Sarosiek T, Szczylik $\mathrm{C}$ : Antisense therapy in cancer. Cancer Treat Rev 2000;26:333-350.

-93 Gottesman MM, Fojo T, Bates SE: Multidrug resistance in cancer: Role of ATP-dependent transporters. Nat Rev Cancer 2002;2:48-58.

-94 Elbashir SM, Harborth J, Lendeckel W, Yalcin A, Weber K, Tuschl T: Duplexes of 21nucleotide RNAs mediate RNA interference in cultured mammalian cells. Nature 2000; 411:494-498.

-95 Kerbel RS: Inhibition of tumor angiogenesis as a strategy to circumvent acquired resistance to anti-cancer therapeutic agents. Bioessays 1991;13:31-36.

-96 Hanahan D, Bergers G, Bergsland E: Less is more, regularly: Metronomic dosing of cytotoxic drugs can target tumor angiogenesis in mice. J Clin Invest 2000;105:1045-1047.

97 Klement G, Baruchel S, Rak J, Man S, Clark K, Hicklin DJ, Bohlen P, Kerbel RS: Continuous low-dose therapy with vinblastine and VEGF receptor-2 antibody induces sustained tumor regression without overt toxicity. J Clin Invest 2000;105:R15-R24.

98 Slamon DJ, Leyland-Jones B, Shak S, Fuchs $\mathrm{H}$, Paton V, Bajamonde A, Fleming T, Eiermann W, Wolter J, Pegram M, Baselga J, Norton L: Use of chemotherapy plus a monoclonal antibody against HER2 for metastatic breast cancer that overexpresses HER2. N Engl J Med 2001;344:783-792.

-99 Messa C, Russo F, Caruso MG, Di Leo A: EGF, TGF-alpha, and EGF-R in human colorectal adenocarcinoma. Acta Oncol 1998; 37:285-289.

100 Porebska I, Harlozinska A, Bojarowski T: Expression of the tyrosine kinase activity growth factor receptors (EGFR, ERB B2, ERB B3) in colorectal adenocarcinomas and adenomas. Tumour Biol 2000;21:105-115.

101 Salomon DS, Brandt R, Ciardiello F, Normanno N: Epidermal growth factor-related peptides and their receptors in human malignancies. Crit Rev Oncol Hematol 1995; 19: 183-232.

102 Saltz L, Rubin MS, Hochster HS: Cetuximab (IMC-C225) plus irinotecan (CPT-11) is active in CPT-11 refractory colorectal cancer that expresses epidermal growth factor receptor (abstract). Prog Proc Am Soc Clin Oncol 2001;20:3a.

103 Saltz LB, Meropol NJ, Loehrer PJ Sr, Needle MN, Kopit J, Mayer RJ: Phase II trial of cetuximab in patients with refractory colorectal cancer that expresses the epidermal growth factor receptor. J Clin Oncol 2004;22:12011208.
104 Cunningham D, Humblet Y, Siena S, Khayat D, Bleiberg H, Santoro A, Bets D, Mueser M, Harstrick A, Verslype C, Chau I, Van Cutsem E: Cetuximab monotherapy and cetuximab plus irinotecan in irinotecan-refractory metastatic colorectal cancer. N Engl J Med 2004; 351:337-345.

105 Chen ZS, Furukawa T, Sumizawa T: ATPdependent efflux of CPT-11 and SN-38 by the multidrug resistance protein (MRP) and its inhibition by PAK-104P. Mol Pharmacol 1999;55:921-928.

106 Chu XY, Suzuki H, Ueda K, Kato Y, Akiyama S, Sugiyama Y: Active efflux of CPT-11 and its metabolites in human KB-derived cell lines. J Pharmacol Exp Ther 1999;288:735741.

107 Meyers MB, Merluzzi VJ, Spengler BA, Biedler JL: Epidermal growth factor receptor is increased in multidrug-resistant Chinese hamster and mouse tumor cells. Proc Natl Acad Sci USA 1986;83:5521-5525.

108 Meyers MB, Yu P, Mendelsohn J: Crosstalk between epidermal growth factor receptor and P-glycoprotein in actinomycin D-resistant Chinese hamster lung cells. Biochem Pharmacol 1993;46:1841-1848.

109 Naruse I, Ohmori T, Ao Y, Fukumoto H, Kuroki T, Mori M, Saijo N, Nishio K: Antitumor activity of the selective epidermal growth factor receptor-tyrosine kinase inhibitor (EGFRTKI) Iressa (ZD1839) in an EGFR-expressing multidrug-resistant cell line in vitro and in vivo. Int J Cancer 2002;98:310-315.

110 Sclabas GM, Fujioka S, Schmidt C, Fan Z, Evans DB, Chiao PJ: Restoring apoptosis in pancreatic cancer cells by targeting the nuclear factor-kappaB signaling pathway with the anti-epidermal growth factor antibody IMCC225. J Gastrointest Surg 2003;7:37-43.

111 Bandyopadhyay D, Mandal M, Adam L, Mendelsohn J, Kumar R: Physical interaction between epidermal growth factor receptor and DNA-dependent protein kinase in mammalian cells. J Biol Chem 1998;273: 1568-1573.

112 Huang SM, Harari PM: Modulation of radiation response after epidermal growth factor receptor blockade in squamous cell carcinomas: Inhibition of damage repair, cell cycle kinetics, and tumor angiogenesis. Clin Cancer Res 2000;6:2166-2174

113 Ciardiello F, Tortora G: Epidermal growth factor receptor (EGFR) as a target in cancer therapy: Understanding the role of receptor expression and other molecular determinants that could influence the response to antiEGFR drugs. Eur J Cancer 2003;39:13481354.

114 Hurwitz H, Fehrenbacher L, Novotny W, Cartwright T, Hainsworth J, Heim W, Berlin J, Baron A, Griffing S, Holmgren E, Ferrara N, Fyfe G, Rogers B, Ross R, Kabbinavar F: Bevacizumab plus irinotecan, fluorouracil, and leucovorin for metastatic colorectal cancer. N Engl J Med 2004;350:2335-2342. 
115 Jain RK: Normalizing tumor vasculature with anti-angiogenic therapy: A new paradigm for combination therapy. Nat Med 2001;7:987-989.

- 116 Willett CG, Boucher Y, di Tomaso E, Duda DG, Munn LL, Tong RT, Chung DC, Sahani DV, Kalva SP, Kozin SV, Mino M, Cohen KS, Scadden DT, Hartford AC, Fischman AJ, Clark JW, Ryan DP, Zhu AX, Blaszkowsky LS, Chen HX, Shellito PC, Lauwers GY, Jain RK: Direct evidence that the VEGF-specific antibody bevacizumab has antivascular effects in human rectal cancer. Nat Med 2004; 10:145-147.
117 Ambudkar SV, Dey S, Hrycyna CA, Ramachandra M, Pastan I, Gottesman MM: Biochemical, cellular, and pharmacological aspects of the multidrug transporter. Annu Rev Pharmacol Toxicol 1999;39:361-398.

118 Altuvia S, Stein WD, Goldenberg S, Kane SE, Pastan I, Gottesman MM: Targeted disruption of the mouse mdr1b gene reveals that steroid hormones enhance mdr gene expression. J Biol Chem 1993;268:27127-27132.

119 Sorrentino BP: Gene therapy to protect haematopoietic cells from cytotoxic cancer drugs. Nat Rev Cancer 2002;2:431-441.
120 Schoenfield A, Luqmani YA, Sinnett HD, Shousha S, Coombes RC: Keratin 19 mRNA measurement to detect micrometastases in lymph nodes in breast cancer patients. $\mathrm{Br} \mathrm{J}$ Cancer 1996;74:1639-1642.

121 Pantel K, von Knebel Doeberitz M: Detection and clinical relevance of micrometastatic cancer cells. Curr Opin Oncol 2000;12: 95-101.

122 Zehentner BK: Detection of disseminated tumor cells: Strategies and diagnostic implications. Expert Rev Mol Diagn 2002;2: $41-48$. 